Chapter 2

\title{
Climate Risk Assessment for Water Resources \\ Development in the Niger River Basin Part I: Context and Climate Projections
}

\author{
J. G. Grijsen, C. Brown, A. Tarhule, Y. B. Ghile, \\ Ü. Taner, A. Talbi-Jordan, H. N. Doffou, A. Guero, \\ R. Y. Dessouassi, S. Kone, B. Coulibaly and \\ N. Harshadeep
}

Additional information is available at the end of the chapter

http://dx.doi.org/10.5772/56707

\section{Introduction}

\subsection{Study area}

Climate change has emerged as one of the most important challenges of the 21st century. Consequently, a plethora of studies has appeared which focus on adaptation measures for responding to the climate change threat. A cursory review of much of the adaptation literature shows, however, that most of it contains little more than generic recommendations to vaguely defined or specified threats. This situation results from the fact that generally the specific impacts of climate change in specific locations or to specific sectors remain poorly understood and under-investigated. This situation is especially acute in Africa where adaptation strategies are urgently needed. In this chapter, we present the results of a study designed to identify and quantify specific impacts of climate change to the hydro-energy, environmental, and agroeconomic sectors in the Niger Basin in West Africa.

The Niger River is the second largest river in Africa by discharge volume (5,600 $\mathrm{m}^{3} / \mathrm{s}$ at Onitsha; 1955-1991) and the third longest (4,100 km). Taking its source on the interior side of the Guinea Daro Massif at an altitude of 1068 meters, the Niger River runs off in a northeasterly direction towards the Niger Inland Delta. At Tossaye (Taoussa, Republic of Mali), the river turns southeast forming the Great Bend and flows on through Niger to Lokoja in Nigeria, where it receives its largest and most important tributary, the Benue River (Fig. 1). From there, the 
enlarged Niger runs directly south to empty into the Bight of Benin through a network of distributaries in Nigeria's Terminal Niger Delta. The river's unusual flow path delineates a drainage basin that is boomerang-shaped and bounded approximately by latitudes $5^{\circ} \mathrm{N}$ and $22^{\circ} \mathrm{N}$ and by longitudes $11^{\circ} 30^{\prime} \mathrm{W}$ and $15^{\circ} \mathrm{E}$. The Niger Basin's total drainage area is 2,170,500 $\mathrm{km}^{2}$ although $35 \%\left(770,500 \mathrm{~km}^{2}\right)$ of the basin lies within the hyper-arid Sahara and contributes no runoff to the Niger River. The Niger Basin cuts across all the major climatic zones of West Africa, including the Guinean or Equatorial forest zone, the Transitional tropical belt, the Sudan Savanna zone, the semi-arid or Sahel savanna belt, and the desert region. Rainfall, temperature, humidity and evaporation all exhibit steep gradients as one moves hinterland from the coast (Fig. 2).

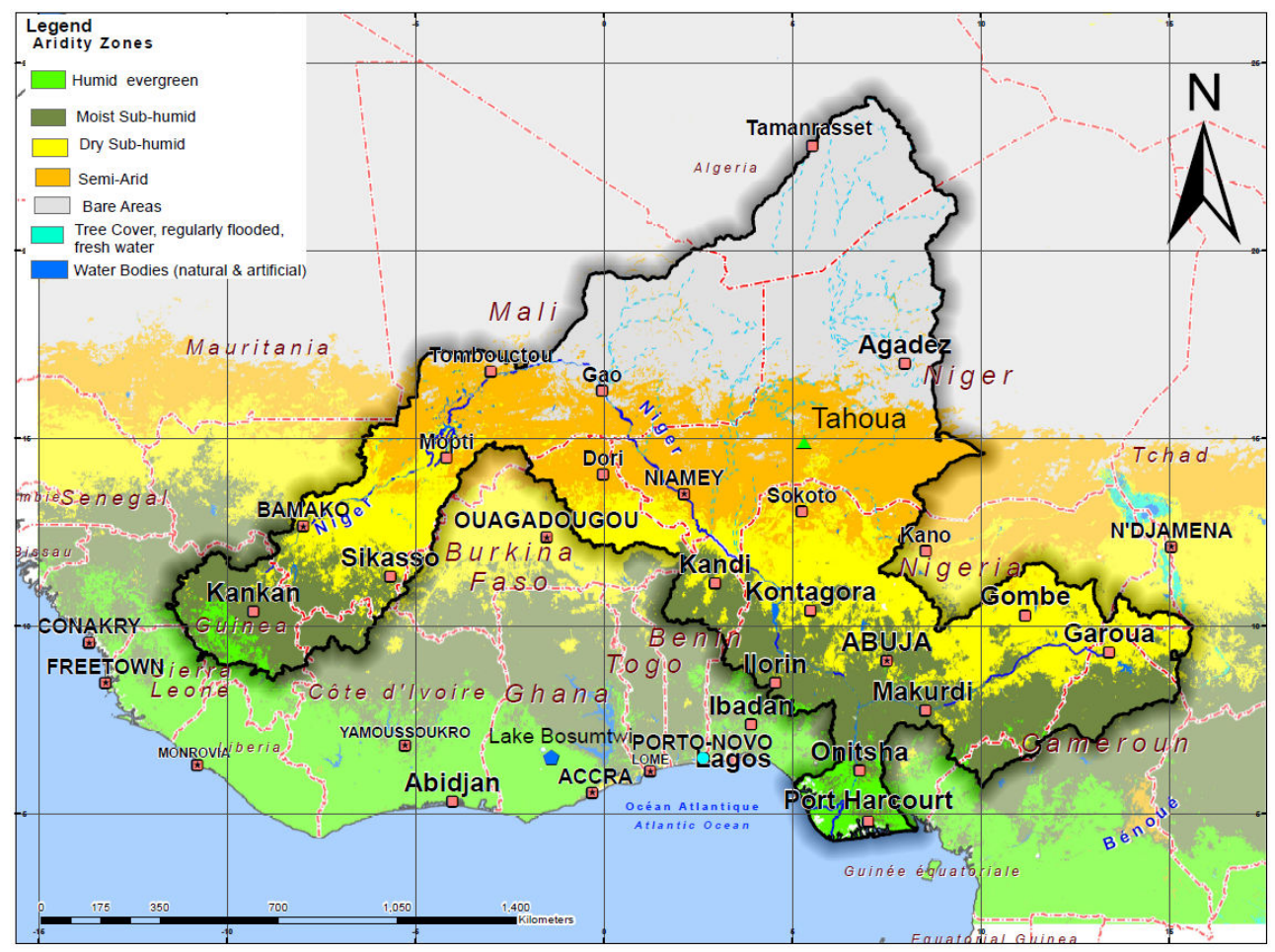

Figure 1. The Location of the Niger Basin in West Africa. Source: BRLi, 2007.

The Niger Basin is experiencing considerable pressures on ecosystem resources and with good reason: all 9 countries in the active basin rank among the bottom 40 countries on the Human Development Index (UNDP, 2010). Over 100 million people inhabit the Niger basin distributed in nine countries, namely Benin, Burkina Faso, Cameroon, Chad, Cote D'Ivoire, Guinea, Mali, Niger, and Nigeria (Fig. 1). Average population growth rate is estimated at $2.7 \%$ and the rate of urbanization at $4.3 \%$, both numbers among the highest rates in the world (UNFPA, 2010). 


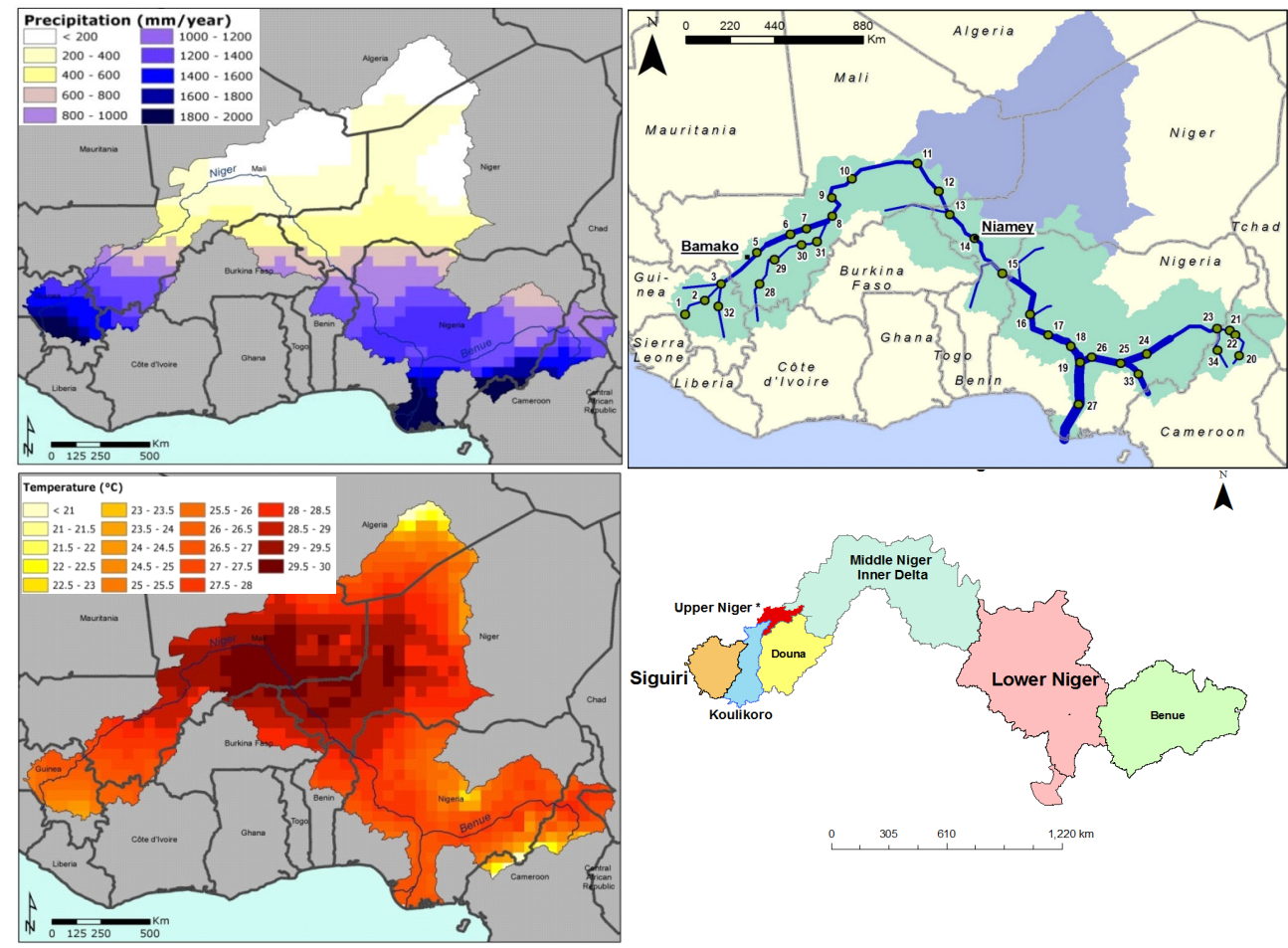

Figure 2. The climatic characteristics of the Niger Basin. The panel on the top left shows the distribution of annual average precipitation, the panel on the top right shows the basin demarcated into active and inactive parts. Also shown is the location of river gauging sites within the basin. The bottom left panel shows the distribution of annual average temperature. Finally, the bottom right panel shows the basin divided into commonly recognized sub-basins. The Upper Niger Basin includes all of the sub basins above the Inner Delta (red area) i.e. Siguiri, Koulikoro (or Sélingué) and Douna (or Bani) watersheds.

Approximately $70 \%$ of the population depends on agriculture for their livelihood and overwhelmingly on rain-fed agriculture, and $60 \%$ lack access to a developed source of water. Somewhat paradoxically, the basins' environmental and water resources are currently grossly underutilized. The irrigation potential is estimated at 2.5 million hectares (ha) but less than 0.3 million ha have been developed; hydropower generation potential is estimated at 30,000 gigawatt hours per year but only 6000 gigawatt hours have been developed; and of the basin's $3,000 \mathrm{~km}$ of navigation potential, only $600 \mathrm{~km}$ is currently utilized (The World Bank, 2005).

Recognizing the development imperatives, the governments of the member states negotiated and adopted in 2002 a shared vision for development, titled the Sustainable Development Action Plan (SDAP) Under the umbrella of the Niger Basin authority (NBA). With expected total investments of US\$ 8 billion over the period 2005 - 2025, the SDAP aims to (i) provide new social and economic opportunities for more than 100 million people living in the Niger Basin, (ii) contribute to capacity building in integrated water resources management, and (iii) 
protect natural resources and ecosystems (BRLi, 2007). A major part of SDAP (80\%) focuses on the construction of three new dams ${ }^{1}$ on the Upper and Middle Niger with associated irrigated agriculture and hydro-energy generation, along with the rehabilitation of existing dams ${ }^{2}$, and improved navigation and water supply.

As part of SDAP implementation, the Executive Secretariat of the NBA and the World Bank (WB) have jointly implemented a Climate Risk Assessment (CRA) initiative for the NRB. This chapter presents a robust methodology for assessing climate change impacts on the Sustainable Development Action Plan (SDAP).

The CRA initiative is prudent because of a history of marked climate variability with significant socio-economic and environmental impacts. Archival records show evidence of a regional, multi-decadal drought between 1738 and 1756, centered on the Great Bend of the River Niger but extending far south into the coastal areas of present day Ghana. Famine during this period killed half of the population of Timbuktu and other areas of the Niger Bend (Curtin, 1975). In contrast, most of the 1780s experienced excessive rainfall, as far North as Agadez in Niger. More recently, since 1970, the semi-arid Soudan and Sahel savanna zones within the region have witnessed the most dramatic example of inter-decadal climatic variability ever measured quantitatively on the planet since instrumental records have been kept (Rasmusson and Arkin, 1993; Hulme, 2001, p.20; Lebel et al., 2003). Average annual rainfall amounts fell by between $25 \%$ and $40 \%$, depending on the location, and persisted over the next two decades, prompting some researchers to hypothesize about whether such decline represented evidence of climate change (Demarée, 1990). Widespread environmental desiccation driven by diminished rainfall and land use practices prompted routine discussions of the "expanding" or "encroaching" Sahara (Lamprey, 1975; Eckholm and Brown, 1977; Los Angeles Times, 1988).

Within this historical context, this CRA is urgent given the expected future impacts of climate change in this region (e.g. IPCC, 2007). Because of the substantial uncertainty in climate projections from the current Global Circulation Models (GCMs), it is difficult to estimate what the future climate is likely to be. This CRA thus aims to better understand the dynamics of the future climate over the NRB, and to assess its potential impacts on water resources, energy, navigation, agriculture and environment, as well as possible consequences for the design of existing and planned infrastructure. Finally, it assesses also the potential negative impacts on the Economic Internal Rate of Return (EIRR) of the SDAP. This is essential for assisting decision makers and stakeholders to better manage their resources, prepare for extreme hydrological hazards, and enhance development planning in the NRB. The CRA assessed the risks of climate change to the water resources and associated development sectors of the Niger Basin in the near (2030), mid (2050), and distant future (2070).

The study is presented in two separate chapters. This chapter introduces the study area, followed by an overview of the study approach and methodology, including the operational definition of risks adopted. Next, the impacts of potential changes in runoff on the SDAP -

1 Fomi dam in Guinea, Taoussa dam in Mali and Kandadji dam in Niger, referred hereafter as the FO-TA-KD development scenario.

2 Kainji and Jebba dams on the main Niger River in Nigeria, and Lagdo dam on the Benue River in Cameroon 
based on an existing water resources allocation model for the basin - are presented (vulnerability analysis). Finally, the adopted approach to projection of climate changes is described. The next chapter discusses the methodology used in estimating the runoff response to climate change, assess climate risks for key water related sectors, as well as the economic internal rate of return.

\section{Overview of approach and methodological framework}

An essential step for climate related adaptation strategies is to estimate the risk (probability) of exceedance of critical impact levels for various impacted sectors. Such probabilities provide better insights about the likelihood that a specific climate change impact may occur, contributing to informed decisions on investments and adaptations. For this reason, we adopted a risk-based analysis framework. The premise of the study is that estimates of the plausibility of climate risks will help to develop a conceptual framework for adaptation strategies that increase the resilience and robustness of the SDAP investment plan in the NRB.

The adopted methodology is as follows (Ghile et. al, 2013):

i. The impacts of changes in runoff on SDAP performance indicators were estimated using an existing Niger River Basin water resources system model (MIKEBASIN) by parametrically varying the hydrological conditions for the period 1966/67 - 1988/89 (vulnerability analysis). The runoff elasticities of selected performance indicators ${ }^{3}$ were then determined (Brown and Grijsen, 2013).

ii. Based on the Intergovernmental Panel on Climate Change (IPCC) A1B scenario, we estimated the probability distributions of changes in precipitation and temperature, using a bias corrected ensemble of 38 Global Climate Model (GCM) projections of future climate for the $21^{\text {st }}$ century.

iii. Using a variety of hydrologic models and methods, we determined the response of runoff to climate changes (defined as climate elasticity ${ }^{4}$ of runoff) and translated the probability distributions of future changes in precipitation and temperature into probability distributions of future mean runoff (Grijsen and Brown, 2013).

iv. Finally, we estimated the probabilities of changes in SDAP performance based on impacts of runoff changes and the assessed probability distributions of changes in runoff.

\footnotetext{
3 The runoff elasticity of a performance indicator (e.g. hydro-energy production) defines the response (as a multiplier) of the indicator to changes in runoff; for example, a runoff elasticity of hydro-energy of 1.2 indicates that a $10 \%$ decrease in runoff would cause a $12 \%$ decrease in generated hydro-energy.

4 Climate elasticity of runoff defines the response (as a multiplier) of runoff to changes in precipitation and temperature; for example, a precipitation elasticity of runoff of 2.5 indicates that a $10 \%$ decrease in rainfall would cause a $25 \%$ decrease in runoff. Similarly, a temperature elasticity of runoff of -0.5 indicates that an increase in temperature of $10 \%$ (e.g. from 26 to $28.60 \mathrm{C}$ ) would cause a decrease in runoff of $5 \%$.
} 


\subsection{Defining climatic risk in the Niger Basin}

In this study climate risk is defined on the basis of changes in annual runoff as a function of projected precipitation and temperature changes; it does not take into account other sources of risk such as vulnerability of specific sectors and future socio-economic changes, nor does it account for changes in the variability of runoff within the year. As mentioned previously, we used an ensemble of 38 climate model runs to account for model error and natural climate variability, and also to obtain the full range of possible climate futures and associated runoff. Each run was treated as equally plausible. Using these runs the probability distributions of future runoff regimes, centered on the years 2030, 2050 and 2070 were fitted to estimate the plausibility of climate risks. To assess the severity and probability of climate-imposed risks in the basin, the generated future mean flows from the 38 climate projections were used to estimate risk levels for key performance metrics. In consultation with basin stakeholders in a CRA workshop in Ouagadougou (2010), reductions of more than $20 \%$ from the baseline performance were considered to be significant impacts. With this guidance, we identified five risk levels ranging from "Mild risk" to "Extreme risk" (Fig. 3), based on a choice of percentage shifts in performance relative to baseline operations. In this study the baseline refers to a development scenario in which three dams are built, along with associated irrigation infrastructure. These dams include Fomi (FO; in the Republic of Guinea), Taoussa (TA; in the Republic of Mali) and Kandadji (KD; in the Republic of Niger). Thus, the baseline scenario is interchangeably referred to as the FO-TA-KD scenario. We focused on five sectors and key performance metrics, as identified by the Ouagadougou CRA workshop participants and shown in Table 1.

\section{Risk levels}
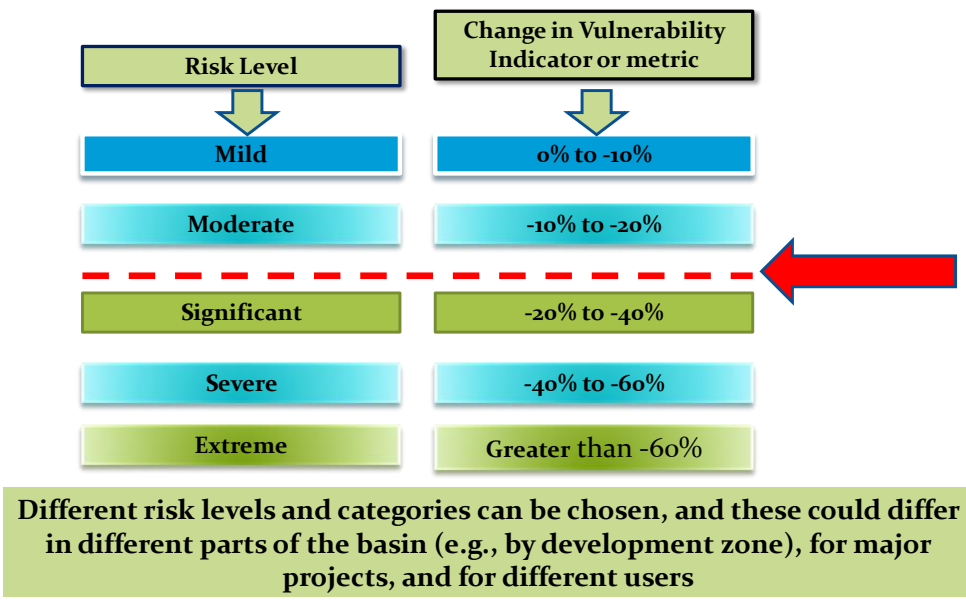

Figure 3. Risk levels based on change in vulnerability indicators. The red arrow indicates the $20 \%$ reduction in performance relative to base level beyond which impacts are considered significant. 


\begin{tabular}{|l|c|c|}
\hline \multicolumn{1}{|c|}{ Sector/ Domain } & Indicator & Baseline \\
\hline Agriculture/irrigation & Incremental net irrigated area & $1.5 \mathrm{Mha}$ \\
\hline Energy production & Total annual energy production & $8,250 \mathrm{GWh}$ \\
\hline Navigation & Annual number of days & $5 \mathrm{months}^{-2}$ \\
\hline $\begin{array}{l}\text { Inner Delta Fooding } \\
\text { Environmental Hows (at } \\
\text { Markala, Mali-Niger border, } \\
\text { Niamey and Malanville) }\end{array}$ & Average annual flooded area & $11,000 \mathrm{~km}^{2}$ \\
\hline
\end{tabular}

Table 1. Key Performance Indicators and baseline values for various sectors

\subsection{Climate projections}

Climate projections typically lack credibility at the spatial and temporal scales that are relevant to water resources planning, especially in tropical regions where monsoonal systems are poorly represented and inter-annual variability is poorly reproduced. While a variety of downscaling approaches are available which change the resolution of climate projections, they do little to improve their credibility. In this analysis we have attempted to address these concerns in two ways. First, as described above, a bottom-up (decision-scaling) approach to assessing risks was adopted (Brown et. al, 2012), which focuses primarily on the vulnerability of the water resources system performance to runoff changes due to climate change. As a result, the climate projections are placed in the context of risks to investments rather than as credible projections of the future. Second, the climate projections were not downscaled to higher resolution; instead, the hydrologic response of the basin was "up-scaled" to better match the resolution at which climate projections have more credibility, i.e. at the basin scale. These approaches represent an attempt to make the best use of the highly uncertain climate information described further below.

Precipitation projections for West Africa vary widely, such that GCMs even lack agreement on the direction of future changes in precipitation (Figs. 4 - 5). Therefore, we analyzed precipitation and temperature projections from an ensemble of $38 \mathrm{GCM}$ simulations ${ }^{5}$ for the $21^{\text {st }}$ century, to capture a quantitative global assessment of climate-change-driven risks for the key metrics identified in the NRB. The projections were driven by the median $\mathrm{A} 1 \mathrm{~B} \mathrm{CO}_{2}$ emission scenario (Nakicenovic and Swart, 2000). To correct for systematic biases inherent in all GCM models, we employed the quantile mapping method - as described in Wood (2002), Wood (2004) and Segui (2010), and trained it on observed and simulated data for the $20^{\text {th }}$ century. It was initially assessed that the estimation of climate risks over the entire NRB would be the most skillful scale for projections. This analysis was done for the periods 2016-2045, 2036-2065 and 2056-2085, considered representative respectively for 2030, 2050 and 2070.

We have also used climate change projections available for Guinea and Nigeria from the climate wizard website ${ }^{6}$ (climatewizard.org) and the WBG's Climate Change Knowledge 
Portal (Climate Portal)- as being representative for respectively the Upper Niger Basin and the Lower Niger and Benue Basins - to determine whether climate change impacts in the Upper Niger (Guinea) and Benue (mainly Nigeria) Basins could be more or less severe than the average impacts across the Niger Basin. The Upper Niger and Benue Basins constitute the main water sources ('water towers') of the Niger River. Results are shown in Table 2, showing a good agreement between the various sources of climate change projections.

Niger Basin - Differences between GCMs, in terms of Change in Annual Precipitation by the 2050s

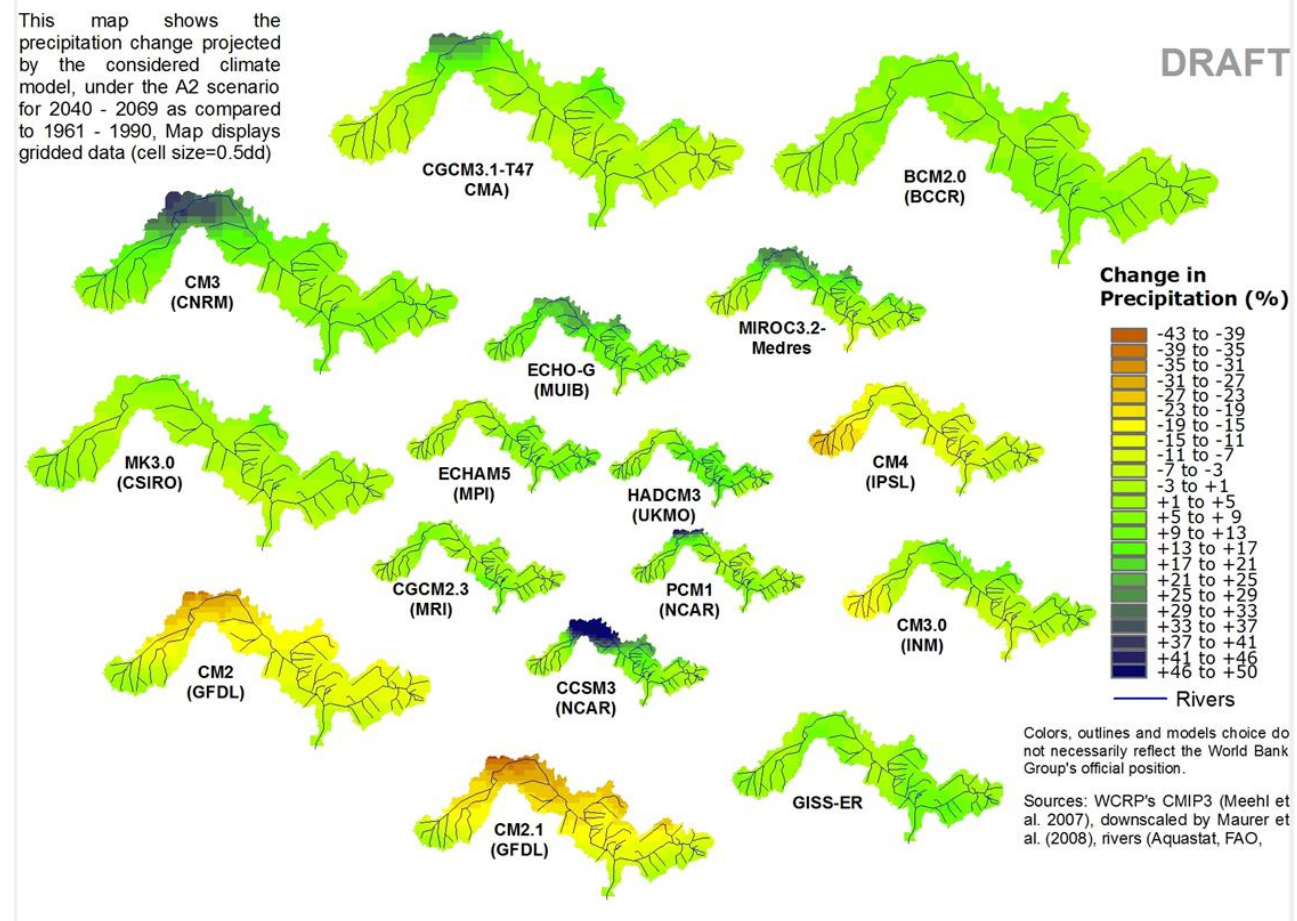

Figure 4. Annual precipitation changes projected for 2050 by various $\mathrm{GCMs}^{7}$ (Sources: right lower corner)

Strzepek (2011) provides a detailed account of the studies and hydrological modeling underpinning the results displayed in the Climate Portal. To generate a high-resolution understand-

6 University of Washington and the Nature Conservancy (2009); Data source: Global Climate Model (GCM) output, from the World Climate Research Program's (WCRP) Coupled Model Inter-comparison Project phase 3 (CMIP3) multi-model dataset (Meehl et al., 2007), was downscaled (as per Maurer et al., 2009) using the bias-correction/spatial downscaling method of Wood et al. (2004) to a 0.5 degree grid, based on the 1950-1999 gridded observations of Adam and Lettenmaier (2003).

7 The largest changes are projected for regions with low rainfall, which has small implications in absolute terms. 


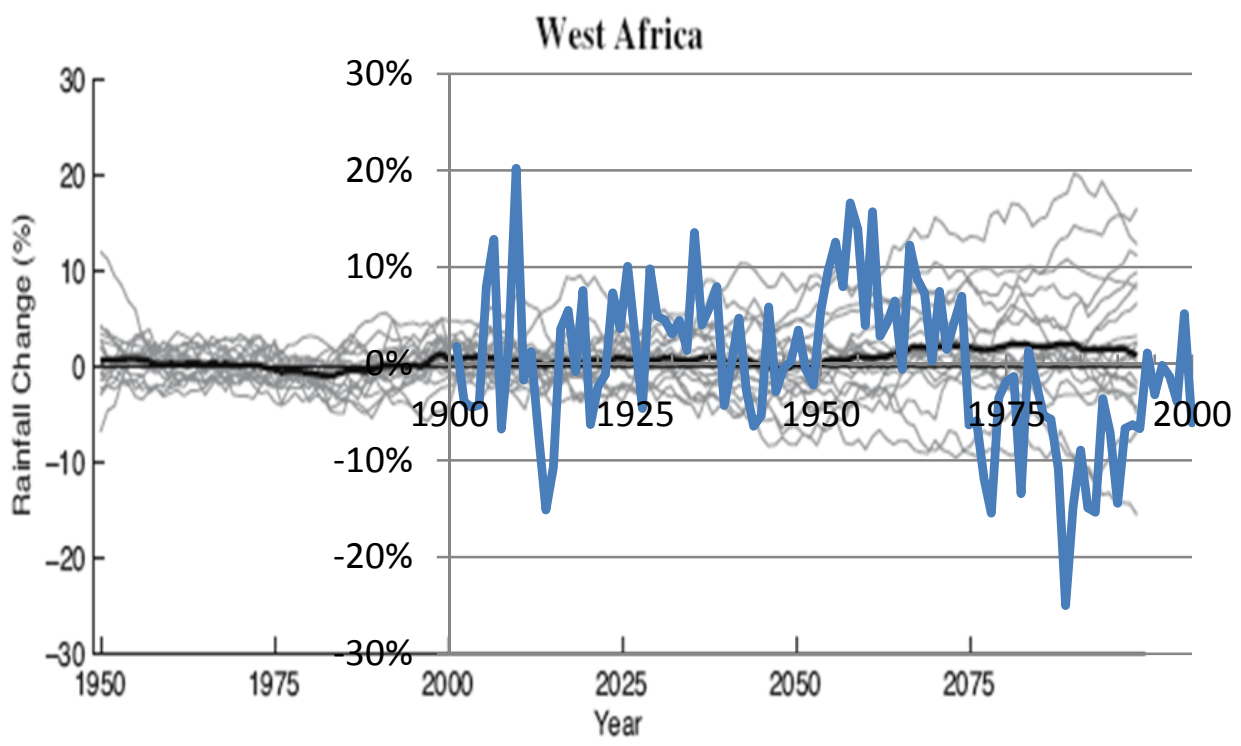

Figure 5. Ensemble of regional climate projections for West Africa (Giannini et al., 2008); the black line is the ensemble mean (A1B); the bold blue line reflects the historical $20^{\text {th }}$ century rainfall variability for the Niger River Basin

ing of possible risks, the analyses examined relative changes in several hydrological indicators (including inter alia annual precipitation, temperature and mean runoff, high flow, low flow and potential evapotranspiration $\left(\mathrm{E}_{0}\right)$ ) from the historical baseline (1961 to 1999) to the 2030s and 2050s, for a range of 56 GCM and emission scenario combinations. Projected changes in runoff and $\mathrm{E}_{0}$ were simulated with the CLIRUN-II hydrologic model II (Strzepek and Fant, 2010), an extension of the WatBal water balance model (Yates, 1996). The results provide an understanding of the range of potential consequences of climate change on water resources at the country and basin scale. The results are claimed to be suitable for use as inputs to screeninglevel analyses of the impact of climate change on water resources dependent investments, for the 2050 investment horizon. Results for the various sources of climate projections agree very well with the results obtained under the present NRB-CRA study on the basis of 38 GCM model runs. Differences between impacts for the two countries are marginal. The Climate Portal shows potential evapotranspiration to increase by nearly $5 \%$ in 2050, or a climate sensitivity of $\mathrm{E}_{0}$ of $2.3 \%$ per ${ }^{0} \mathrm{C}$ at an average annual basin temperature of $26.6{ }^{\circ} \mathrm{C}$.

The results show that a slightly larger number of models project increases in precipitation than those projecting decreases, while all the models project increases in temperature. Fig. 6 shows quartiles of rainfall and temperature projections $(0,25,50,75$ and $100 \%$ points), for percentage changes relative to the $20^{\text {th }}$ century averages. The graphs show variations of the 30 -yr average across the 38 GCM model runs, for 2030, 2050 and 2070, interpreted as the variance of the projected future mean runoff. 


\begin{tabular}{|c|c|c|c|c|c|c|}
\hline Variable & Min & $20 \%$ & Mean & $80 \%$ & Max & S. dev. \\
\hline \multicolumn{7}{|c|}{ Climatewizard.org } \\
\hline \multicolumn{7}{|l|}{ Guinea } \\
\hline Temperature $\left({ }^{0} \mathrm{C}\right)$ & 1.8 & 2.0 & 2.3 & 2.8 & 3.0 & \\
\hline Precipitation (\%) & -20.0 & -6.0 & 0.0 & 6.0 & 10.0 & \\
\hline \multicolumn{7}{|l|}{ Nigeria } \\
\hline Temperature $\left({ }^{0} \mathrm{C}\right)$ & 1.5 & 1.8 & 2.1 & 2.5 & 2.8 & \\
\hline Precipitation (\%) & -15.0 & -4.0 & 2.0 & 10.0 & 15.0 & \\
\hline \multicolumn{7}{|c|}{ WBClimate Change Knowledge Portal } \\
\hline \multicolumn{7}{|l|}{ Guinea } \\
\hline Temperature $\left({ }^{0} \mathrm{C}\right)$ & 1.2 & 1.8 & 2.1 & 2.6 & 3.0 & 0.5 \\
\hline Precipitation (\%) & -12.2 & -5.2 & 0.5 & 5.6 & 12.9 & 6.8 \\
\hline Annual runoff (\%) & -23.8 & -13.5 & -0.3 & 12.0 & 38.7 & 16.5 \\
\hline Annual PET (\%) & 0.7 & 3.9 & 5.0 & 6.7 & 8.1 & 1.7 \\
\hline \multicolumn{7}{|l|}{ Nigeria } \\
\hline Temperature $\left({ }^{0} \mathrm{C}\right)$ & 1.2 & 1.6 & 2.0 & 2.4 & 2.7 & 0.4 \\
\hline Precipitation (\%) & -13.4 & -4.4 & 1.2 & 7.0 & 10.9 & 6.4 \\
\hline Annual runoff (\%) & -31.0 & -11.3 & -0.2 & 15.1 & 29.9 & 17.0 \\
\hline Annual PET (\%) & 1.5 & 3.7 & 4.6 & 6.1 & 7.4 & 1.4 \\
\hline \multicolumn{7}{|c|}{ Projections 38 GCM model runsfor Niger River Basin } \\
\hline Temperature $\left({ }^{0} \mathrm{C}\right)$ & 1.2 & 1.6 & 2.1 & 2.6 & 2.9 & 0.5 \\
\hline Precipitation (\%) & -5.8 & -3.5 & 1.4 & 4.5 & 13.7 & 4.5 \\
\hline Annual runoff (\%) & -19.5 & -13.2 & -1.9 & 4.7 & 32.3 & 10.9 \\
\hline Annual PET (\%) & 2.6 & 3.6 & 4.7 & 5.8 & 6.7 & 1.1 \\
\hline
\end{tabular}

Table 2. Summary of projected climate changes from various sources (2050; A1B)

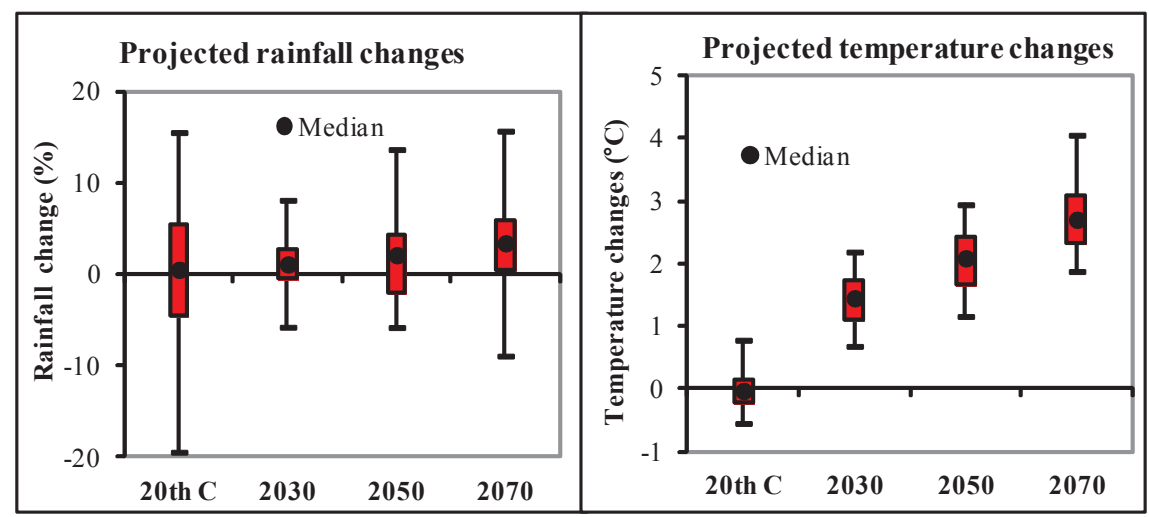

Figure 6. Quantiles for rainfall and temperature changes ${ }^{8}$ for the $20^{\text {th }}$ century and projections for 2030,2050 and 2070

8 The average baseline temperature for the 20 th century is $26.60 \mathrm{C}$ 
Fig. 7 depicts annual rainfall and temperature projections for the $21^{\text {st }}$ century averaged for each year over all GCM runs. It shows hardly any upward trend in precipitation till 2050 and 3\% by $2070 ; 34(90 \%)$ of the 38 model runs project by 2050 changes between $-6 \%$ and $+7 \%$. Temperatures show a steady increase of $0.03^{\circ} \mathrm{C}$ per year $\left(2.9^{\circ} \mathrm{C}\right.$ over 100 years); on average $2.1^{\circ} \mathrm{C}(8 \%)$ by 2050 and $2.7^{\circ} \mathrm{C}$ by $2070(10 \%)$. Projected temperature increases vary between $+1.0^{\circ} \mathrm{C}$ and $+3.0^{\circ} \mathrm{C}$ by 2050 . The primary impact of increased temperatures by 2050 is an increase of the potential evapotranspiration by about $5 \%$ for a $2.1^{\circ} \mathrm{C}$ increase in temperature (Grijsen, 2013), and a similar increase in gross irrigation requirements. Catchment runoff is generally also reduced due to increased evaporation, as discussed in Part II. The normal distribution has been shown to apply well to the 30-year average projections of precipitation and temperature for 2050 (Fig.8).

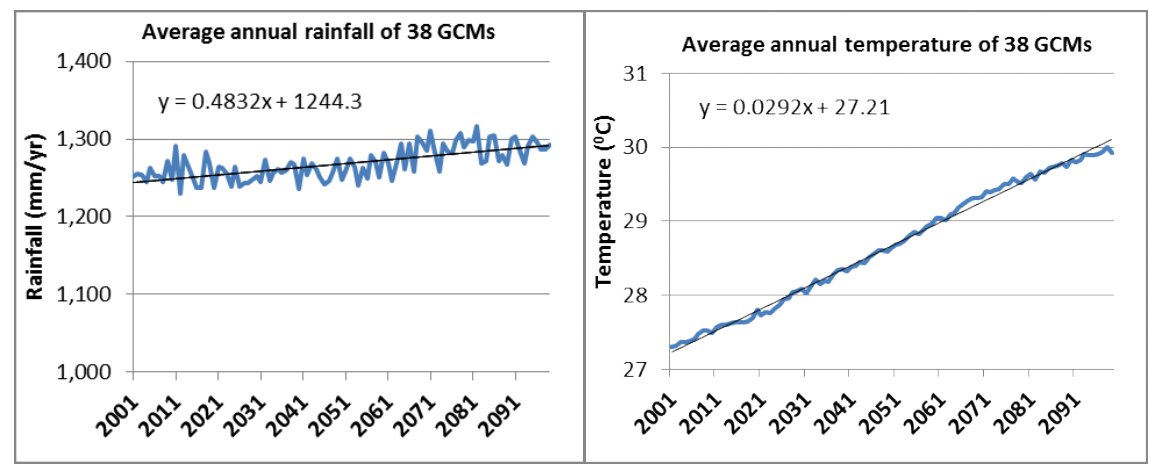

Figure 7. Annual rainfall and temperature projections for the $21^{\text {st }}$ century averaged over all GCMs runs
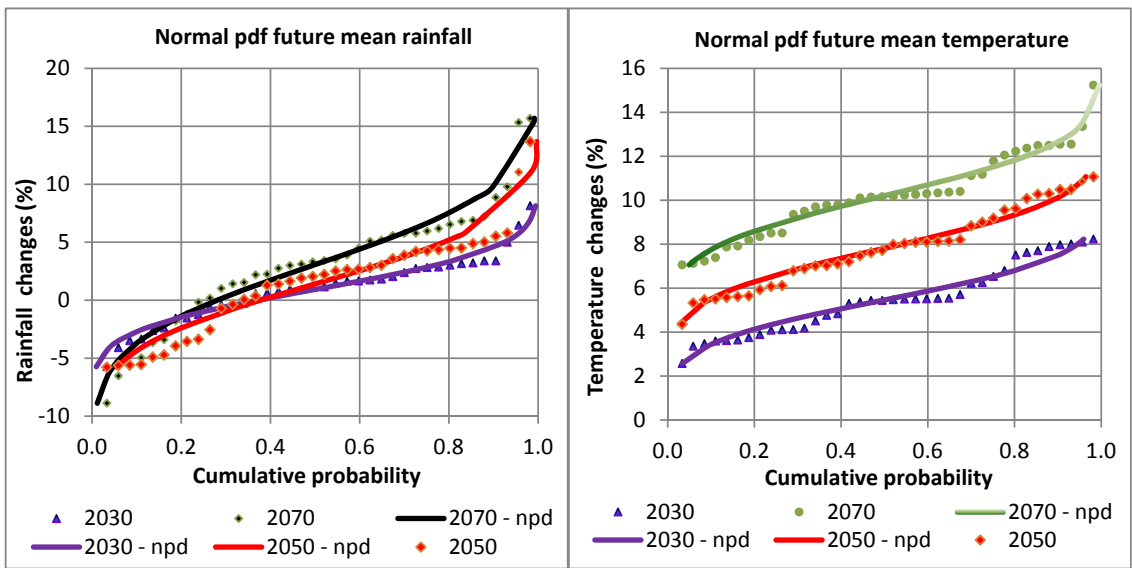

Figure 8. Normal distribution of projected average precipitation and temperature for $2030-2070$ 


\subsection{Assessing impacts of potential runoff changes on key SDAP performance indicators}

In 2007, a Mike-Basin water resources system model was developed for the NRB to study the impact of various SDAP development scenarios on the water resources of the Basin (BRLi, 2007). We have adopted this model to simulate the water availability, water demands and water abstractions from the river and reservoir system within the NRB. The Mike Basin model is designed to simulate and assess the balance between the abstractions of water for irrigation and domestic and industrial water supply on the one hand, and energy production, flooding, navigation and environmental constraints (required minimum flows) at any location of interest on the other hand. The model requires input in the form of hydrological data (including streamflow, rainfall and potential evapotranspiration), reservoir characteristics and operating rules, minimum environmental flows, water demand series for domestic needs and irrigation, hydro-electric power generation parameters, and multiple socio-economic parameters (for irrigated agriculture, hydro-energy, navigation, environmental benefits and cost, etc.). The NRB has been divided into 60 sub-catchments, with 420 river nodes, 21 existing and 4 planned dams, 10 hydropower plants, and 93 water abstraction points for various uses (Fig. 9). The model was calibrated and verified with historical hydro-meteorological data for the period 1966/67 - 1988/89. This period contains some years with above average flow conditions during the 1960s, but is dominated by the drought conditions during the 1970s and 1980s, with below average flow conditions as shown in Fig. 10.

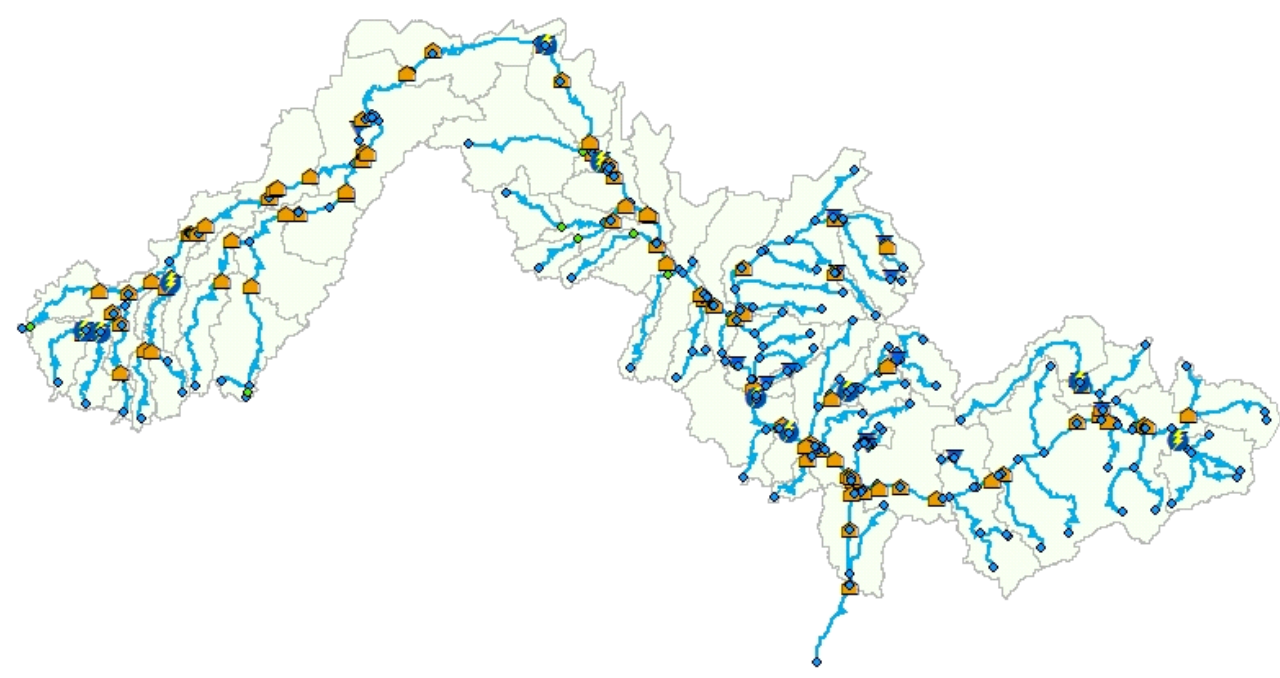

Figure 9. Schematization of the Mike Basin model for the Niger Basin. 


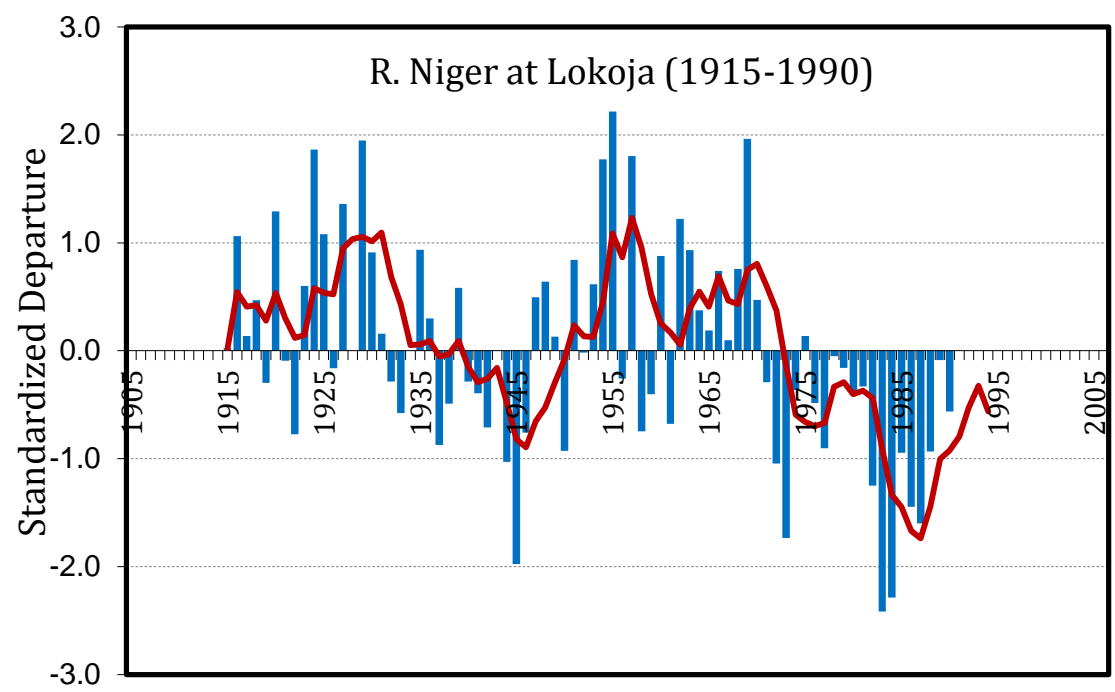

Figure 10. Standardized annual flow data for Lokoja at the confluence of the main Niger and Benue Rivers.

The relationships between relative changes in runoff and relative changes in specific performance criteria at basin level were derived from numerous Mike-Basin runs for the FO-TA-KD development scenario, for parametrically induced variations in runoff between $-30 \%$ and + $10 \%$ of the $20^{\text {th }}$ century baseline conditions, and water demands with a $5 \%$ increase compared to the $20^{\text {th }}$ century baseline (Table 3). The average projected temperature increase by 2050 is $2.1^{\circ} \mathrm{C}$. Based on the Penman-Monteith and modified Hargreaves methods this is estimated to cause an increase of $5 \%$ in potential evapotranspiration and crop water demand (Grijsen, 2013). Fig. 11 shows the runoff changes required to cause specific changes in selected performance indicators, such as $-10 \%,-20 \%$ etc. The $1 / 5$ yrs $(20 \%)$ performance indicators are slightly more sensitive to runoff changes than the average performances.

Under the FO-TA-KD development scenario irrigated agriculture will receive a major boost, increasing the average total harvested area by $440 \%$. The average basin wide hydro-energy production is estimated to increase due to SDAP by $13 \%$ (including the contributions of multiple run-of-river hydro-plants) and the average navigable months in the NRB are estimated to decrease by about $20 \%$. Flooding of the Inner Delta will face a decrease of about $10 \%$ due to SDAP. However, hydro-energy production at Kainji and Jebba dams on the main stem Niger River in Nigeria will face a decrease of nearly 35\%, caused by the large incremental upstream irrigation water withdrawals. Minimum flows in the Middle Niger will be significantly improved, while minimum flows through the Inner Delta will remain well above the required $40 \mathrm{~m}^{3} / \mathrm{s}$.

Table 3 demonstrates the sensitivity of performance indicators for changes in runoff. Significant reductions of more than $20 \%$ of the baseline performance generally occur for hydro-energy production, flooding of the Inner Delta and navigation when the long-term average basin 


\section{Runoff impacts on average of indicators}

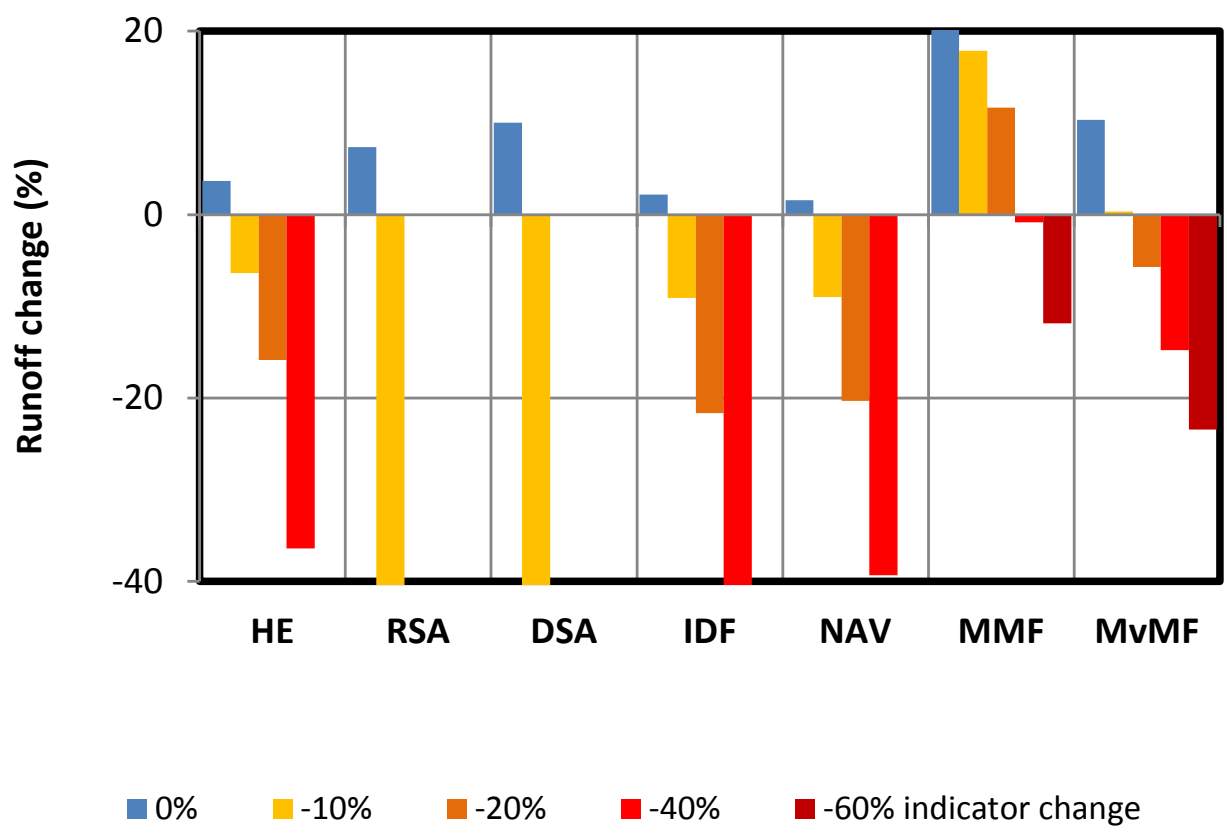

Figure 11. Runoff changes required to generate specific changes in performance indicators

runoff decreases by 15 to $20 \%$, or more. Such long-term average decrease would represent a major increase in the aridity of the basin'. This sensitivity to runoff changes is attributed to the fact that energy production is not prioritized in the applicable water allocation rules under the existing Water Charter for the Niger Basin. The Charter assigns the highest priority to irrigation and domestic water supply to secure food production and alleviate poverty. Thus, irrigated agricultural is the least sensitive to climate change impacts on basin runoff. Moreover, during the rainy season water availability remains abundant and secures in most years full replenishment of reservoirs for dry season irrigation, even after significant flow reductions. Minimum flows at Markala (upstream of the Inner Delta) and in the Middle Niger (Table 3) are extremely sensitive to changes in basin runoff and cannot be maintained even under a $10 \%$ reduction in runoff. This is reflected in the runoff elasticity of performance indicators (last column of Table 3), defined as the ratio between relative changes in an indicator and relative changes in runoff ${ }^{10}$. Runoff elasticities of performance indicators can thus be divided in three groups, i.e. (i) irrigated agriculture with a runoff elasticity of 0.1 to 0.2 (non-sensitive); (ii) hydro-energy, navigation and Inland Delta flooding with runoff elasticities of 1.0 to 1.3 (sensitive), and (iii) minimum flows with elasticities of 2 to 4 (extremely sensitive). The dry

9 It is noted that the droughts of the 1970s and 1980s are already reflected in the 2005 baseline flow regime. 
season minimum flows are also very sensitive to increased dry season irrigation demands due to climate change.

\begin{tabular}{|c|c|c|c|c|c|c|c|c|c|c|}
\hline \multirow{2}{*}{$\begin{array}{l}\text { Performance } \\
\text { Metrics }\end{array}$} & \multirow{2}{*}{$\begin{array}{c}\text { Probability } \\
\text { of non- } \\
\text { exceedance }\end{array}$} & \multirow{2}{*}{\begin{tabular}{|c} 
Reference \\
2005 (SA) \\
Value \\
\end{tabular}} & \multirow{2}{*}{$\begin{array}{l}\text { Impacts } \\
\text { FO-TA-KD } \\
\% \text { change }\end{array}$} & \multicolumn{6}{|c|}{$20^{\text {th }} \mathrm{C}+5 \%$ water demands; FO-TA-KD } & \multirow{2}{*}{$\begin{array}{l}\text { Average } \\
\text { runoff } \\
\text { elasticity }\end{array}$} \\
\hline & & & & $\begin{array}{l}20^{\text {th }} \mathrm{GR} \\
\text { Value }\end{array}$ & $+10 \% R$ & $\begin{array}{l}0 \% \mathrm{R} \\
\text { Percen }\end{array}$ & $\begin{array}{l}-10 \% R \\
\text { tage chan }\end{array}$ & $\begin{array}{l}-20 \% R \\
\text { ges(\%) }\end{array}$ & $-30 \% R$ & \\
\hline \multicolumn{11}{|l|}{ Hydro-energy } \\
\hline Basin energy & $1 / 2(50 \%)$ & 7,376 & 12.6 & 8,303 & 5.2 & -3.0 & -13.9 & -24.3 & -33.8 & 1.0 \\
\hline (GWh) & $1 / 5(20 \%)$ & 5,771 & 3.4 & 5,969 & 8.9 & -3.5 & -16.0 & -28.5 & -38.7 & 1.3 \\
\hline \multirow[t]{2}{*}{ Kainji/Jebba } & $1 / 2(50 \%)$ & 5,007 & -32.5 & 3,381 & 11.1 & -5.8 & -23.0 & -37.3 & -48.2 & 1.7 \\
\hline & $1 / 5(20 \%)$ & 3,743 & -43.9 & 2,100 & 9.8 & -5.1 & -21.3 & -38.0 & -50.3 & 1.7 \\
\hline \multicolumn{11}{|c|}{ Irrigated Agriculture } \\
\hline Total irrigation & mean & 228,138 & 435 & 1,2२०,591 & 0.1 & -0.3 & -0.9 & -1.8 & -3.6 & 0.1 \\
\hline RS(ha) & $1 / 5(20 \%)$ & २2৪,138 & 424 & $1,194,537$ & -0.1 & -0.5 & -2.1 & -4.2 & -8.1 & 0.2 \\
\hline Total irrigation & mean & 111,744 & 471 & 637,537 & -0.4 & -0.8 & -1.2 & -1.5 & -2.2 & 0.1 \\
\hline DS(ha) & $1 / 5(20 \%)$ & 105,130 & 500 & 630,890 & -0.7 & -0.9 & -1.4 & -5.5 & -15.7 & 0.3 \\
\hline \multicolumn{11}{|c|}{ Navigation for various reaches (average number of days) } \\
\hline Average & Large boats & 171 & -20.9 & 135 & 7.9 & -1.4 & -10.9 & -19.7 & -30.2 & 1.0 \\
\hline Hooding $\left(\mathrm{km}^{2}\right)$ & mean & 12,117 & -9.7 & 10,940 & 5.4 & -1.5 & -10.9 & -18.7 & -28.6 & 0.9 \\
\hline Inland Delta & $1 / 5(20 \%)$ & 10,342 & -14.1 & 8,887 & 7.1 & -1.6 & -13.9 & -24.8 & -37.3 & 1.2 \\
\hline \multicolumn{11}{|c|}{ Sustenance of 10-day average minimum flows $\left(\mathrm{m}^{3} / \mathrm{s}\right)$} \\
\hline \multirow[t]{2}{*}{ Markala } & $1 / 2(50 \%)$ & 70 & -13 & 61 & -25.0 & -38.6 & -54.7 & -83.5 & -100.0 & 4 \\
\hline & $1 / 5(20 \%)$ & 51 & -2 & 50 & -31.1 & -40.6 & -69.8 & -99.6 & -100.0 & 5 \\
\hline \multirow{2}{*}{$\begin{array}{l}\text { Mali-Niger } \\
\text { border }\end{array}$} & $1 / 2(50 \%)$ & 60 & 33 & 80 & -2.7 & -12.3 & -32.6 & -65.2 & -89.0 & 3 \\
\hline & $1 / 5(20 \%)$ & 12 & 547 & 80 & -15.9 & -32.3 & -63.9 & -82.1 & -97.4 & 4 \\
\hline \multirow[t]{2}{*}{ Niamey } & $1 / 2(50 \%)$ & 55 & 78 & 99 & 2.0 & -9.2 & -16.9 & -37.5 & -80.9 & 2 \\
\hline & $1 / 5(20 \%)$ & 9 & 818 & 85 & -0.9 & -11.3 & -33.6 & -73.7 & -97.0 & 3.5 \\
\hline \multirow[t]{2}{*}{ Malanville } & $1 / 2(50 \%)$ & 68 & 35 & 91 & -0.3 & -10.3 & -27.2 & -53.9 & -71.6 & 2.5 \\
\hline & $1 / 5(20 \%)$ & 4 & 2,035 & 77 & -2.1 & -21.9 & -55.8 & -83.5 & -98.2 & 4 \\
\hline
\end{tabular}

Table 3. Performance indicator matrix for the FO-TA-KD scenario (-10\% R means a $10 \%$ reduction of runoff)

\section{Conclusions}

Effectively managing climate change will constitute one of the major challenges of the $21^{\text {st }}$. This challenge will be especially acute in those regions of the world already prone to adverse climatic variability and where the financial and technical resources for dealing with climate change are lacking. The River Niger Basin in West Africa fits this profile. However, in collaboration with several donor and investment partners, the member states of the Niger

10 A runoff elasticity of +1.5 indicates that a $10 \%$ decrease in runoff causes a $15 \%$ decrease in performance. 
Basin under the aegis of the Niger Basin Authority are implementing a novel climate risk assessment study in an effort to climate-proof new investments. This chapter described a part of that study, including an over view of the methodology, a description of the climate change estimation procedure and an assessment of the impact of potential runoff changes on key SDAP performance indicators. The key conclusions of the study will be summarized in the next chapter (part II).

Climate change confronts decision makers with deep uncertainty, where decisions can go wrong if decision makers assume that risks are well-characterized while in reality uncertainties could be underestimated. Such conditions require robust decision making to inform good decisions by identifying system vulnerabilities and assessing alternatives for ameliorating those vulnerabilities. A water resources system model and the Performance Indicator Matrix (Table 3) prepared on the basis of a large number of model simulations, provide a powerful tool to identify early on in the CRA process, even before climate projections have been processed, system vulnerabilities and future climate change conditions where the proposed SDAP plan may fail to meet its goals. These conditions can then be used to early identify potential actions to address vulnerabilities and evaluate tradeoffs among them. This approach, which focuses on water resources system vulnerability rather than on climate change projections, is considered crucial in view of the large uncertainties embedded in the presently available climate projections for the $21^{\text {st }}$ century.

\section{Acknowledgements}

This study was done as part of the Climate Risk Assessment (CRA) for the Niger Basin, a joint initiative of the Niger Basin Authority (NBA) and the World Bank to assess the risks from climate change to the performance of NBA's Sustainable Development Action Plan (SDAP) for the Niger Basin. The aim of this initiative is to build resilience to climate risks into the SDAP. The Niger CRA study is supported by grants from (i) the Bank-Netherlands Partnership Program (BNPP) Trust Fund, (ii) the Trust Fund for Environmentally and Socially Sustainable Development (TFESSD) funded by Finland and Norway, (iii) the Norwegian Trust Fund (NTF) and (iv) the Trust Fund for Integrated Land and Water Management for Adaptation to Climate Variability and Change (ILWAC) funded by Denmark. We gratefully acknowledge the NBA Observatory for making hydro-meteorological and runoff data available, as well as providing valuable comments and directions for the study. We extend our thanks to Dr. Amal Talbi for managing this CRA study for the World Bank, and to the World Bank's Water Partnership Program (WPP) and Water Unit for organizing the special session S3 of HydroPredict2012 (Vienna, September 2012) on 'Choosing Models for Resilient Water Resources Management' (Grijsen et. al, 2013), and for giving permission to present the results of this CRA work in this book. We thank the World Bank for permission to report this work here. 


\section{Author details}

J. G. Grijsen ${ }^{1}$, C. Brown², A. Tarhule ${ }^{3 *}$, Y. B. Ghile ${ }^{4}$, Ü. Taner ${ }^{5}$, A. Talbi-Jordan ${ }^{6}$, H. N. Doffou ${ }^{7}$, A. Guero ${ }^{7}$, R. Y. Dessouassi', S. Kone', B. Coulibaly ${ }^{7}$ and N. Harshadeep ${ }^{8}$

*Address all correspondence to: atarhule@ou.edu

1 Independent Hydrology and IWRM Consultant, Texas, USA

2 Department of Civil and Environmental Engineering, University of Massachusetts, Amherst, USA

3 Department of Geography and Environmental Sustainability, University of Oklahoma, Norman, USA

4 Woods Institute for the Environment, Stanford University, Stanford, USA

5 Dept. of Civil and Environmental Engineering, University of Massachusetts, Amherst, USA

6 The World Bank Middle East North Africa (MNSWA), Washington, USA

7 Niger Basin Authority/ Autorité du Bassin du Niger (ABN), Niamey, Niger

8 The World Bank, Africa Region, Washington DC, USA

\section{References}

[1] BRLi et alJanuary (2007). Evaluation des prélèvements et des besoins en eau pour le modèle de simulation du basin du Niger, Final Report.

[2] BRLi et alJuly (2007). Elaboration du Plan d'Action de Développement Durable du Bassin du Niger, Phase II : Schéma Directeur d'Aménagement et de Gestion.

[3] BRLi et alSeptember (2007). Establishment of a Water Management Model for the Niger River Basin, Final Report.

[4] Brown, C, \& Grijsen, J. G. (2013). Sensitivity of SDAP performance to changing water availability and demands; the Niger River Basin Climate Risk Assessment, a joint initiative of the Niger Basin Authority and the World Bank (not yet disclosed).

[5] Brown, C, Ghile, Y, Laverty, M, \& Li, K. (2012). Decision scaling: linking bottom-up vulnerability analysis with climate projections in the water sector, Water Resources Research, 48(9), 1-12 
[6] Curtin, P. D. (1975). Economic Change in Pre-Colonial Africa: Supplementary Evidence, University of Wisconsin Press, Madison.

[7] Demaréee, G. R. (1990). An indication of climatic change as seen from the rainfall data of a Mauritanian station, Theoretical and Applied Climatology, , 42, 139-147.

[8] Eckholm, E, \& Brown, L. R. (1977). Spreading deserts-The hand of man, World watch Paper Washington D.C.(13)

[9] Giannini, A, Biasutti, M, Held, I. M, \& Sobel, A. H. (2008). A global perspective on African climate, Climatic Change, 90(4), 359-383.

[10] Ghile, Y. B, Taner, M. Ü, Brown, C, \& Grijsen, J. G. (2013). Bottom-up Climate Risk Assessment of Infrastructure Investment in the Niger River Basin, Climate Change (under review)

[11] Grijsen, J. G. (2013). Future Water Demands in the Niger Basin, the Niger River Basin Climate Risk Assessment, a joint initiative of the Niger Basin Authority (NBA) and the World Bank (not yet disclosed).

[12] Grijsen, J. G, \& Brown, C. (2013). Climate elasticity of runoff and climate change impacts in the Niger River Basin; the Niger River Basin Climate Risk Assessment, a joint initiative of the Niger Basin Authority (NBA) and the World Bank (not yet disclosed).

[13] Grijsen, J. G, Brown, C, \& Tarhule, A. Climate Risk Assessment for Water Resources Development in the Niger River Basin; HydroPredict'(2012). International Conference on Predictions for Hydrology, Ecology and WRM, Special Session S3- Choosing models for resilient water resources management, Vienna; World Bank WET/WPP/ TWIWA publication (in print)., 2012.

[14] Hulme, M. (2001). Climatic perspectives on Sahelian desiccation: 1973-1998. Global Environmental Change , 11, 19-29.

[15] IPCCKundzewicz, Z.W., L.J. Mata, N.W. Arnell, P. Döll, P. Kabat, B. Jiménez, K.A. Miller, T. Oki, Z. Sen and I.A. Shiklomanov, (2007). Freshwater resources and their management. Climate Change 2007: Impacts, Adaptation and Vulnerability. Contribution of Working Group II (Chapter 3) to the Fourth Assessment Report of the Intergovernmental Panel on Climate Change, M.L. Parry, O.F. Canziani, J.P. Palutikof, P.J. van der Linden and C.E. Hanson, Eds., Cambridge University Press, Cambridge, UK, , 173-210.

[16] Lamprey, H. F. (1975). Report on the desert encroachment reconnaissance in northern Sudan, 21 Oct. to 10 Nov., 1975; UNESCO/UNEP.

[17] Lebel, T, Redelsperger, J. L, \& Thorncroft, C. (2003). African Monsoon Multidisciplinary Analysis (AMMA): an international research project and field campaign; CLIVAR Exchanges , 8, 52-54. 
[18] Los Angeles Times(1988). Desert Encroachment: Fabled Oasis of Timbuktu Is Drying Up; byline by Scott Kraft, March 08, 1988; available online at http://articles.latimes.com/1988-03-08/news/mn-608_1_desert-encroachment;last accessed September 3, 2012.

[19] Maurer, E. P, Adam, J. C, \& Wood, A. W. (2009). Climate Model based consensus on the hydrologic impacts of climate change to the Rio Lempa basin of Central America, Hydrology and Earth System Sciences, 13, 183-194.

[20] Meehl, G. A, Covey, C, Delworth, T, Latif, M, Mcavaney, B, Mitchell, J. F. B, Stouffer, R. J, \& Taylor, K. E. (2007). The WCRP CMIP3 multi-model dataset: A new era in climate change research, Bulletin of the American Meteorological Society, , 88, 1383-1394.

[21] Nakicenovic and Swart(2000). Special Report on Emissions Scenarios, Cambridge University Press, Cambridge, UK. Available at http://www.grida.no/climate/ipcc/ emission/023.htm.

[22] Rasmusson, E. M, \& Arkin, P. A. (1993). A global view of large-scale precipitation variability. Journal of Climate , 6, 1495-1522.

[23] Segui, P. Q, Ribes, A, Martin, E, Habtes, F, \& Boe, J. (2010). Comparison of three downscaling methods in simulating the impact of climate change on the hydrology of Mediterranean basins, Journal of Hydrology , 383, 111-124.

[24] Strzepek, K. M, Mccluskey, A, Boehlert, B, Jacobsen, M, \& Fant, C. W. IV, (2011). Climate Variability and Change: A Basin Scale Indicator Approach to Understanding the Risk to Water Resources Development and Management, Water Anchor of the World Bank Group, series Water Papers: WB Water Paper CCK Portal.

[25] Strzepek, K. M, Fant, C. W, \& Water, I. V. and Climate Change: Modeling the Impact of Climate Change on Hydrology and Water Availability, University of Colorado and Massachusetts Institute of Technology.

[26] United Nations Development Program(2010). Human Development Indicators-2010 Rankings. The United Nations Development Program. Available online at http:// hdr.undp.org/en/media/PRHDR10-HD1-E-rev4.pdf.

[27] United Nations Population Fund(2010). The state of the world population: Demographic and economic indicators. UNPFA. Available online at http://www.unfpa.org/swp.

[28] World Bank(2005). The Niger River Basin: A vision for sustianable management. The World Bank. Available online at http://elibrary.worldbank.org/content/book/ 9780821362037.

[29] Yates, D. (1996). WatBal: An integrated water balance model for climate impact assessment of river basin runoff. International Journal of Water Resources Development , 12(2), 121-139. 
[30] Wood, A. W, Maurer, E. P, Kumar, A, \& Lettenmaier, D. P. (2002). Long-range experimental hydrologic forecasting for the eastern United States, Journal of Geophysics Research 107(D20), 4429.

[31] Wood, A. W, Leung, L. R, Sridhar, V, \& Lettenmaier, D. P. (2004). Hydrologic implications of dynamical and statistical approaches to downscaling climate model outputs, Climate Change , 62, 189-216. 